\title{
IAMJ
}

INTERNATIONAL

AYURVEDIC

MEDICAL JOURNAL

ISSN: 2320-5091

Impact Factor: 6.719

\section{A CRITICAL ANALYSIS OF ATATVABHINIVESHA AS MAHAGADA, AND ITS MODERN INTERPRETATION}

\author{
Raviprasd Hegde ${ }^{1}$, Suhas Kumar Shetty ${ }^{2}$ \\ ${ }^{1}$ Associate Professor, Department of Manovijnana avum Manasaroga, Alva's Ayurveda Medical College, \\ Moodubidire, Karnataka, India \\ ${ }^{2}$ Professor and HOD, Department of Manovijnana avum Manasaroga, SDM College of Ayrveda and Hospital, \\ Hassan, Karnataka, India
}

Corresponding Author: raviprasadhegde@gmail.com

\section{https://doi.org/10.46607/iamj1709052021}

(Published Online: May 2021)

Open Access

(C) International Ayurvedic Medical Journal, India 2021

Article Received:22/04/2021 - Peer Reviewed:04/05/2021 - Accepted for Publication:05/05/2021

Check for updates

\begin{abstract}
Atatvabhinivesha is a disease explained only in Charaka Samhita and considered it as a difficult to treat mental disorder (Mahagada). Budhi Vibhramsha (loss of intellect) is the predominant symptom of Atatvabhinivesha. Because of complete derangement of intellectual capacity person loses his insight towards disease, and self. Modern interpretation for Atatvabhinivesha can be done to the symptoms of Psychosis, where person loses insight and develops psychotic symptoms predominantly delusions and hallucinations.
\end{abstract}

Keywords: Atatvabhinivesha, Mahagada, Psychosis

\section{INTRODUCTION}

Atatvabhinivesha is a disease only explained in Charaka Samhita, while explaining classification of different diseases, and mentioned it as only one $\mathrm{Ma}$ hagada (difficult to cure disease). Acharya Chakrapa- ni commented on it as a mental illness, and it leads to misery in all living being ${ }^{2}$. The word Atatvabhinivesha is the combination of Atatva and Abhinivesh. Atatva is the false, or ayatartha, and Abiniveshaa is interpreta- 
tion. Where there is interpretation of false perceptions by a person, he is not able to recognise truth, and considers false interpretation itself truth, termed as $A t$ atvabhinivesha.

As there is false interpretation over truth in $A t$ atvabhinivesha, and considered it as Mahagada, several major mental diseases which has been associated with symptoms of Psychosis can be interpreted with Atavabhinivesha. Psychosis is seen in many mental disorders, and considered it as severe form of such disease, and needs treatment for longer duration. Psychosis is characterised by loss of contact with reality and relationship with other people causing social maladaptation. Psychosis affects personality, the contact with reality is completely lost, hallucinations and delusions are present and higher risk of self harm ${ }^{3}$.

Some of the different types of psychosis include

1. Schizophrenia

2. Schizoaffective disorders

3. Delusional disorder

4. Substance induced psychosis

5. Dementia and Delirium

6. Bipolar disorder

7. Major Depressive disorder

8. Postpartum psychosis

9. Psychosis due to general medical condition.

Aetiology of Atatvabhinivesha are indulging in regular intake of impure food, suppression of the manifested natural urges, excessive indulging in diet which are opposite qualities each other such as cold - hot, unctuous - un unctuous ${ }^{4}$.

Impure food like unprocessed meat is the cause for increased Dopamine hormone in post synaptic receptors, and which leads to psychotic disorders ${ }^{5}$.

Suppression of natural urges aggravates vatadaosha, and vata and manas are interrelated ${ }^{6}$. Aggravation of vata also aggravates mano dosha rajas and tamas.

Excessive indulge in diet which are opposite qualities can be correlated with substance abuse like alcohol or cannabis which are the cause for psychosis ${ }^{7}$.

The patho - physiology of Atatvabhinivesha is occlusion of aggravated dosha to mind and intellect leading to derangement of intellect ${ }^{8}$. There will be damage to the most important aspect of mind, and because of this, person is unable to identify eternal thing as eternal, and wholesome as wholesome. Rather considers eternal as ephemeral, and wholesome as unwholesome. Complete derangement of intellect, which is superior aspect of mind leading to abnormal functioning of it. Hence Atatvabhinivesha is considered as Mahagada by Acharya Charaka.

The modern interpretation to Atatvabhinivesha is Psychotic disorders, where person loses the insight and suffers from hallucinations and delusions. Hallucination is a perception experienced in the absence of external stimulus. The hallucination can be auditory, visual, olfactory, gustatory, or tactile domains ${ }^{9}$.

The symptoms of Atatvabhinivesha can be observed in the following disorders in detail.

Schizophrenia: Characterized by disturbance in thought and verbal behaviour, perception. Affect, motor behaviour, and relationship to the external world. All these symptoms are beyond truth. Hallucination is common here, and most frequently auditory hallucinations like,

- Hearing simple sounds

- Audible thought (Thought echo)

- Third person hallucination (voices heard arguing, discussing patients in $3^{\text {rd }}$ person)

Bizarre type of delusions is also observed along with hallucinations, where patient's day to day activities completely disturbed ${ }^{10}$

Schizoaffective Disorder: Characterized by the symptoms of both Schizophrenia, and Mood disorders are prominently present within the same episode. Schizoaffective disorder lies on the borderland between Schizophrenia and Mood Disorder. Psychotic symptoms which were discussed in Schizophrenia are also observed here, along with psychotic symptoms coming under Mood disorder can also observed in this disease ${ }^{11}$.

Delusional Disorders: Most significant symptoms, resembles with Atatvabhinivesha are observed in Delusional Disorder. Previously called by name "Paranoid Disorder", where patient strongly believes untruth as truth. It is not at all possible to change his belief. That is unshakable belief in something untrue ${ }^{12}$. Different types of delusions are as follow, 
- Erotomanic delusions (Delusions of love or Claerambautt's syndrome or Erotomania): Observed most often in women. There is an erotic conviction that a person with higher status in love with the patient.

- Delusions of Grandiose: The patient usually has delusions with religious or political content and may believe self to be a leader with higher aims of spreading peace, making war, or spreading a message in the world.

- Delusions of Jealousy (Othello syndrome or conjugal paranoia): The content of delusions is predominantly jealousy(infidelity) involving spouse, in which a person is preoccupied with the thought of their spouse or sexual partner is being unfaithful without having any proof.

- Delusions of Persecution: The most commonly seen delusional disorder. Affected patient believe they are being persecuted despite being lack of evidence.

- Somatic Delusion (Hypochondrical): Common delusions include infections by worms or foreign bodies emitting foul odor (Delusional Halitosis), body being ugly or misshapen (Delusional dysmorphophobia).

- Nihilistic Delusions: Delusional belief of being dead, having lost one's own internal organs, not existing entirely as a human being.

All the above types of delusions are of non - bizarre type, where the person completely normal outside the delusion. The person can lead near normal life without arousing suspicion regarding their delusional disorder. Substance Induced Psychosis: Alcohol dependence, Cannabis dependence, or withdrawal of any substance, patient develops delusions or hallucinations. For example, Cannabis Psychosis (Hemp insanity), Delirium tremens in Alcoholic withdrawal. Patient develops visual hallucination and illusions, which are often vivid and frightening, Tactile hallucinations of insects crawling over body are the symptoms observed in Alcoholic induced psychosis ${ }^{13}$.

Delirium and Dementia: Two organic mental disorders with the symptoms of psychosis like hallucina- tions, and delusions are observed in Delirium, and in the chronic phase of Dementia ${ }^{14}$.

Bipolar Mood Disorder: Delusions of Grandiose, and delusions of control are usually observed in Manic episode. 15 to $20 \%$ of Depressive patients have psychotic symptoms such as

- Nihilistic delusions

- Delusions of guilt

- Delusions of poverty

- Delusions of control ${ }^{15}$.

Postpartum Psychosis: Postpartum blues, postpartum depression, postpartum psychosis are different conditions a mother experiences after giving birth to child. Hallucinations and delusions are common in the postpartum psychosis ${ }^{16}$.

Psychosis due to general medical condition: Brain tumours, Seizure disorders, Huntington's disease, Multiple Sclerosis, Cushing's syndrome, Vitamin deficiencies, electrolyte abnormalities, Thyroid disorders, Uraemia, SLE, HIV, Anabolic steroids, Corticosteroids, Anti-malarial drugs are some of the causes for onset of psychotic symptoms.

Treatment for Atatvabhinivesha: Kramavat Shodana is advised by Punarvasu Athreya, including Snehana, Swedana, Vamana, Virechana, Basti, Nasya. Due to proper purification person's heart, faculties of senses, head, and throat are cleansed. Person attains clarity in the mind and there by regains memory and orientation. After purificatory procedures Medhya food and liquid like Brahmi swarasa with Panchagavya Gritha, and Shankapushpi is administered. MedyaRasayana is explained specially in the treatment of Atatvabhinivesha, which acts directly on the Budhi, which was deranged completely in the patient suffering from Atatvabhinivesha. At the end Acharya Charaka mentioned SatvavajayaChikithsa by the preceptors and close friends with having sympathy towards patient to teach dharma (right way of living) and artha(right way to earn) ${ }^{17}$.

Even in the contemporary science the first line of treatment for Psychotic symptoms are Antipsychotics. Once patient regains insight about his illness counselling or psychotherapy is done to prevent further relapse of episodes ${ }^{18}$. 
Prognosis of Psychotic Disorders: Depends on several factor, but proper treatment is required for almost lifetime. This factor is also similar in case of Atatvabhinivesha, though the prognosis is not explained in the literature, as it is Mahagada, needs treatment for longer duration.

\section{DISCUSSION}

Atatvabhinivesha is explained by Punarvasu Athreya at the end of the Apasmara Chikithsa. Derangement of intellect leading to symptoms like unable identify eternal and non-eternal, and also unable identify wholesome and unwholesome. Complete derangement of intellect is considered as difficult to treat, hence Atatvabhinivesha is considered as Mahagada (difficult to treat disease). The aetiology, symptoms, management of Psychotic symptom, which are seen in many major mental disorders are almost similar to Atatvabhinivesha.

\section{CONCLUSION}

Atatvabhinivesha explained by Punarvasu Athreya as Mahagada cannot be interpreted with any single modern mental disorder, rather it can be interpreted with the features of Psychosis which are observed in many mental disorders on the basis of aetiology, patho physiology, symptoms, management, and prognosis. Psychosis is needed much more care for lifelong, when compared with management of Neurosis.

\section{REFERENCES:}

1. Agnivesha, Charaka Acharya, Yadavji Trikamj Acharya editor. Charaka Samhita. New Delhi: MunshiramManoharlal Publishers Pvt. Ltd; 1992. P.110

2. Agnivesha, Charaka Acharya, Yadavji Trikamj Acharya editor. Charaka Samhita. New Delhi: MunshiramManoharlal Publishers Pvt. Ltd; 1992. P.111

3. Niraj Ahuja, editor. A Short Textbook of Psychiatry. New Delhi: Jaypee Brothers Medical Publishers (P) Ltd; 2011. P.83

4. Agnivesha, Charaka Acharya, Yadavji Trikamj Acharya editor. Charaka Samhita. New Delhi: Munshiram Manoharlal Publishers Pvt. Ltd; 1992. P.477

5. BBC Good Food. Immediate Media Company Ltd 2020
6. Hatayoga Pradeepa

7. Niraj Ahuja, editor. A Short Textbook of Psychiatry. New Delhi: Jaypee Brothers Medical Publishers (P) Ltd; 2011. P.38

8. Agnivesha, Charaka Acharya, Yadavji Trikamj Acharya editor. Charaka Samhita. New Delhi: MunshiramManoharlal Publishers Pvt. Ltd; 1992. P.477

9. Niraj Ahuja, editor. A Short Textbook of Psychiatry. New Delhi: Jaypee Brothers Medical Publishers (P) Ltd; 2011. P.13

10. Niraj Ahuja, editor. A Short Textbook of Psychiatry. New Delhi: Jaypee Brothers Medical Publishers (P) Ltd; 2011. P.87

11. Niraj Ahuja, editor. A Short Textbook of Psychiatry. New Delhi: Jaypee Brothers Medical Publishers (P) Ltd; 2011. P.83 - 84

12. Niraj Ahuja, editor. A Short Textbook of Psychiatry. New Delhi: Jaypee Brothers Medical Publishers (P) Ltd; 2011. P.83

13. Niraj Ahuja, editor. A Short Textbook of Psychiatry. New Delhi: Jaypee Brothers Medical Publishers (P) Ltd; 2011. P.38

14. Niraj Ahuja, editor. A Short Textbook of Psychiatry. New Delhi: Jaypee Brothers Medical Publishers (P) Ltd; 2011. P.22

15. Niraj Ahuja, editor. A Short Textbook of Psychiatry. New Delhi: Jaypee Brothers Medical Publishers (P) Ltd; 2011. P.70, 72

16. Niraj Ahuja, editor. A Short Textbook of Psychiatry. New Delhi: Jaypee Brothers Medical Publishers (P) Ltd; 2011. P.145 - 146

17. Agnivesha, Charaka Acharya, Yadavji Trikamj Acharya editor. Charaka Samhita. New Delhi: MunshiramManoharlal Publishers Pvt. Ltd; 1992. P.477

18. Niraj Ahuja, editor. A Short Textbook of Psychiatry. New Delhi: Jaypee Brothers Medical Publishers (P) Ltd; 2011. P.65 - 68

\section{Source of Support: Nil Conflict of Interest: None Declared}

How to cite this URL: Raviprasd Hegde \& Suhas Kumar Shetty: A Critical Analysis Of Atatvabhinivesha As Mahagada, And Its Modern Interpretation. International Ayurvedic Medical Journal \{online\} 2021 \{cited May, 2021\} Available from: http://www.iamj.in/posts/images/upload/1050_1053.pdf 